\title{
A (re)invenção de si no entrelaçar das enunciações de gays, travestis e transexuais
}

\author{
Deise Azevedo LONGARAY ${ }^{1}$ \\ Paula Regina Costa RIBEIRO²
}

Introdução

\begin{abstract}
"É possivel moldar a própria subjetividade por um trabalho de si sobre si. Trata-se de criar "estilos de vida" pelos quais tentamos nos desprender dos modos de ser e de pensar legados pela história ou impostos pelas estruturas sociais. Trata-se de reinventar si mesmo, de se recriar." Didier Eribon (2008, p.295).
\end{abstract}

A epígrafe que introduz este texto traz à tona a discussão da constituição dos sujeitos - o recriar-se e o reinventar-se - a partir de outros modos de vida, que não aqueles determinados nos modos fixos da modernidade. De acordo com

1 Doutora em Educação em Ciências. FURG - Universidade Federal do Rio Grande Pós-graduação em Educação em Ciências. Carreiros - RS - Brasil. 96203-900. Pesquisadora do Grupo de Pesquisa Sexualidade e escola - GESE - deiselongaray@ yahoo.com.br

2 Doutora em Ciências Biológicas. UFRGS - Universidade Federal do Rio Grande do Sul - Pós-graduação em Ciências Biológicas. Porto Alegre - RS - Brasil. 90050-170. Professora associada IV. FURG - Universidade Federal do Rio Grande. Carreiros RS - Brasil. 96203-900. Líder do Grupo de Pesquisa Sexualidade e Escola - GESE. Bolsista Produtividade 1C do CNPq - pribeiro.furg@gmail.com 
Eribon (2008), é preciso que façamos a nossa história de outra forma, a partir de um trabalho constante de fabricação de si, desligando-se da estrutura hegemônica e das imposiçôes sociais, seja em relação aos gêneros, às sexualidades, etc.

No mundo contemporâneo, existe uma multiplicidade de maneiras de ser que póem em xeque as diferentes formas de viver a sexualidade, distintos modos de relacionamentos afetivo-sexuais, bem como diferentes modos de viver as masculinidades e as feminilidades. As subjetividades consideradas contrahegemônicas, a exemplo das gays, lésbicas, travestis e transexuais, tornam-se cada vez mais visíveis, rompendo as fronteiras e as permissividades atribuídas aos gêneros e às sexualidades.

A sexualidade é entendida, neste estudo, como uma construção social, histórica e cultural, que envolve relação sexual, posturas, prazeres, desejos, escolhas, relaçóes de carinhos e afetos, entre outros aspectos. Para Foucault (2004b), "[...] a sexualidade faz parte de nossa conduta. Ela faz parte da liberdade em nosso usufruto deste mundo. A liberdade é algo que nós mesmos criamos ela é nossa própria criação, ou melhor, ela não é a descoberta de um aspecto secreto de nosso desejo." Para o autor, os sujeitos são produzidos em meio a práticas de liberdade e a sexualidade e as formas como a vivemos estáo imbuídas nesse processo. Os sujeitos "escolhem" 3 as formas como querem conduzir suas vidas e a liberdade envolvida nesse processo dá-se a partir de relações de coexistência (SOUZA FILHO, 2008).

O processo de (re)invenção de si possibilita aos sujeitos outras formas de relacionamentos, outras configurações familiares, outras formas de amar e desejar, enfim, "novas formas de criação" (FOUCAULT, 2004b). A constituição de si não se dá em um processo fixo e linear, mas de maneira inconclusiva, interminável e constante, em que vários e diferentes enunciados e discursos se entrelaçam a partir de diferentes instâncias e práticas sociais.

Partindo desses pressupostos, este artigo ${ }^{4}$ tem, como objetivo, problematizar um dos enunciados que forma o discurso da homossexualidade. O enunciado analisado é nomeado como a constituição da homossexualidade e as enunciaçôes que o produzem contribuem para justificar a homossexualidade como algo

3 Entendemos a escolha, assim como Foucault, no sentido de liberdade de escolha. De acordo com o autor, "[...] essa liberdade inclui a liberdade de expressão dessa escolha, quer dizer, a de torná-la pública e a de não torná-la pública.” (FOUCAULT, 2000, p.16).

4 Este artigo integra uma tese de doutorado, desenvolvida pelo Programa de PósGraduação em Educação em Ciências, da Universidade Federal do Rio Grande/ FURG e vincula-se à linha de pesquisa Educação Científica: Implicaçóes das Práticas Científicas na Constituição dos Sujeitos. A pesquisa também contou com o apoio do CNPq. 
"natural", no sentido de buscar uma explicação, neste âmbito, para tal subjetividade.

Neste sentido, analisamos narrativas de sujeitos que se autoidentificaram ${ }^{5}$ como gays, travestis e transexuais, problematizando algumas práticas envolvidas nos seus processos de subjetivação. As narrativas foram produzidas a partir de entrevistas realizadas através da Metodologia da História Oral.

$\mathrm{O}$ artigo está organizado em três momentos: Primeiramente, tecemos algumas consideraçôes sobre os modos de subjetivação dos sujeitos. Logo, apresentamos a metodologia de produção das narrativas, os sujeitos que participaram deste estudo e suas histórias, bem como analisamos suas narrativas a partir de algumas ferramentas propostas por Michel Foucault. E, por fim, apontamos algumas consideraçóes acerca da escrita deste artigo.

\section{Teorizações sobre os modos como se constituem os sujeitos}

Michel Foucault, ao longo de seu trabalho, centrou-se na produção de uma história dos diferentes processos de constituição dos sujeitos e, dessa forma, distinguia três modos que transformam os seres humanos em sujeitos: 1) o modo da investigação: que busca o estatuto de ciência, a objetivação do sujeito produtivo, do sujeito falante ou ainda a objetivação do sujeito pelo simples fato de estar vivo; 2) modos de objetivação das práticas divisórias: processo de divisão do sujeito em seu interior ou em relação aos outros; por exemplo, o louco e o são, o criminoso e o não criminoso, o doente e o sadio; e 3) o modo pelo qual o ser humano torna-se sujeito, ou seja, o modo de reconhecimento de sujeito de sexualidade (FOUCAULT, 2010b).

Os modos de subjetivação que constituem os sujeitos de uma sexualidade são produzidos historicamente através de suas relações estabelecidas com outros sujeitos, através de seus modos de ser, estar e agir na sociedade. É a partir das práticas subjetivantes, ou seja, a partir das práticas de $\mathrm{si}^{6}$ que discutiremos, neste estudo, a constituição dos sujeitos de sexualidade, articulando tais discussóes com a produção dos sujeitos gays, travestis e transexuais da contemporaneidade, entendendo que os corpos não assumem um caráter imutável, dotados de uma única forma de viver as sexualidades e os gêneros. Em meio a esta fluidez,

5 Em nenhum momento, ao longo da pesquisa, instituímos os sujeitos participantes deste estudo como gays, travestis ou transexuais, eles/as é que, na entrevista, autoidentificaram-se dessas formas.

6 De acordo com Foucault (2010a, p.276), as práticas de si “[...] não são, entretanto, alguma coisa que o próprio indivíduo invente. São esquemas que ele encontra em sua cultura e que lhe são propostos, sugeridos, impostos por sua cultura, sua sociedade e seu grupo social." 
podemos afirmar que, assim como não existe uma única forma de ser homem e mulher na sociedade, múltiplas e flexíveis também são as relaçóes afetivo-sexuais.

Assim, não há uma única forma de ser heterossexual, homossexual, bissexual, travesti, transexual. Tais subjetividades podem ser vividas de diferentes formas. Para Foucault (2010a, p.274), o sujeito "[...] é uma forma, e essa forma nem sempre é sobretudo, idêntica a si mesma [...]. Há, indubitavelmente, relaçóes e interferências entre essas diferentes formas do sujeito; porém, não estamos na presença do mesmo tipo de sujeito.” Desta maneira, não podemos afirmar que os sujeitos assumem a mesma posição em diferentes espaços, assim como não se pode garantir que os sujeitos são produzidos pelos mesmos discursos ao longo de toda a sua existência. Eles são constituídos de múltiplas formas, a partir de modos distintos e é, neste sentido, que os sujeitos não são os mesmos, uma vez que estabelecem relaçóes diferenciadas com os demais sujeitos de um grupo social. Segundo Foucault (2010a, p.291),

[...] não há um sujeito soberano, fundador, uma forma universal de sujeito que poderíamos encontrar em todos os lugares. [...] o sujeito se constitui através de práticas de sujeição ou, de maneira, mais autônoma, através de práticas de liberaçáo, de liberdade [...] - a partir, obviamente, de um certo número de regras. De estilos, de convençôes que podemos encontrar no meio cultural.

Entendemos que os sujeitos constituem-se em meio a uma trama histórica, produzida por enunciados e por discursos que circulam em determinado contexto e espaço, por acontecimentos e por relações de saber e de poder, constituindo, dessa maneira, diferentes processos de subjetivação. Peres $(2009,2010)$ discute sobre a subjetividade, apresentando, em seus textos, os processos de subjetivação normatizadores e processos de subjetivação singularizadores.

Os processos de subjetivação normatizadores buscam, de alguma forma, manter a norma estabelecida socialmente. Trabalhamos com o conceito de norma a partir das contribuiçóes de François Ewald, entendendo que a norma é

[...] uma maneira de um grupo se dotar de uma medida comum segundo um rigoroso princípio de auto-referência, sem recurso a nenhuma exterioridade, quer seja a de uma ideia quer a de um objecto. Ela pressupóe arquitecturas, dispositivos, toda um física do poder graças à qual o grupo poderá tornar-se visível para si mesmo, mas também procedimentos, notaçôes, cálculos, toda uma constituiçấo de saber destinada a produzir, em completa positividade, o um a partir do múltiplo. (EWALD, 1993, p.108, grifo do autor).

Nesse contexto, a heterossexualidade torna-se a referência na sexualidade, ou seja, a norma, enquanto que as demais subjetividades - gays, lésbicas, travestis, transexuais, entre outras - são tidas como anormais. 
Assim, os processos de subjetivação normatizadores “[...] dizem respeito à produção de sujeitos que reproduzem os modelos previamente dados, e dão manutenção a certo modo de viver disciplinado, regulado e repetitivo." (PERES, 2010). Já os processos de subjetivação singularizadores, "[...] se mostrariam como linhas de fuga, contra-poderes ou resistências frente ao poder que facilitariam a expressão da diferença, da singularidade e de modos desejantes potentes e criativos." (PERES, 2010). A partir dos modos de subjetivação singularizadores, os sujeitos rompem com a norma, tornam-se resistentes a ela. Por este viés, ao refletir sobre a constituição dos sujeitos gays, travestis e transexuais, entendemos que, ora percebemos os processos normatizadores operando, ora os singularizadores. Em alguns momentos, embora tais sujeitos busquem borrar as fronteiras, romper com a "norma heterossexual" e com o processo dicotômico homem/mulher, masculino/feminino, é possível evidenciarmos, a partir de suas posições de sujeito, a permanência e fixação desses binarismos e de modelos hegemônicos.

É partindo deste pressuposto que investigamos, neste estudo, como os sujeitos gays, travestis e transexuais constituem-se, bem como problematizamos a forma como se relacionam com os demais sujeitos ao longo da construção de suas subjetividades. A fim de investigar estas questóes, apresentamos a metodologia de produção das narrativas, bem como os sujeitos participantes deste estudo, problematizando os modos contemporâneos de fabricação das subjetividades gays, travestis e transexuais.

\section{A metodologia de produção das narrativas e os sujeitos participantes da pesquisa}

A História Oral é utilizada, neste estudo, como metodologia de produção das narrativas. De acordo com a Associação Brasileira de História Oral7, "por história oral se entende o trabalho de pesquisa que utiliza fontes orais em diferentes áreas de conhecimento nas quais essa metodologia é utilizada”.

A História Oral privilegia as entrevistas como questão central da pesquisa, ou seja, "[...] história oral como metodologia implica formular as entrevistas como um epicentro da pesquisa. Tudo giraria em torno delas, que atuariam como força centrífuga das preocupaçôes." (MEIHY; HOLANDA, 2010, p.72). O corpus de análise deste estudo é composto por narrativas produzidas a partir de entrevistas realizadas com sujeitos gays, travestis e transexuais. Através da História $\mathrm{Oral}^{8}$, aqueles grupos que constituem as minorias políticas, tais como

7 A Associação Brasileira de História Oral disponibiliza informaçóes sobre a História Oral em: <http://www.historiaoral.org.br/estatuto>. Acesso em: 26 out. 2011.

8 É relevante destacarmos que o espectro da História Oral tem se ampliado, não se 
homossexuais, negros, mulheres, entre outros, e que sofrem com o preconceito social, "[...] têm encontrado espaço para validar suas experiências, dando sentido social aos lances vividos sob diferentes circunstâncias." (MEIHY; HOLANDA, 2010, p.26-27). Optamos pela utilização de entrevistas, a fim de possibilitar que sujeitos que permaneceram e ainda permanecem silenciados/ as sujeitos, a partir de suas narrativas de vida, coloquem em evidência a sua história, as suas singularidades. Para a produção das narrativas utilizamos um roteiro de entrevista flexível, o qual continha questóes norteadoras que contribuíram na condução da mesma.

Levando em consideração que pretendemos analisar como os sujeitos constituem-se e, principalmente, como autoidentificaram-se como sujeitos gays, travestis e transexuais, utilizamos a entrevista temática, uma vez que

[...] a escolha de entrevistas temáticas é adequada para o caso de temas que têm estatuto relativamente definido na trajetória de vida dos depoentes, como, por exemplo, um período determinado cronologicamente, uma função desempenhada ou o envolvimento e a experiência em acontecimentos ou conjunturas específicos. (ALBERTI, 2005, p.38).

As narrativas analisadas são de sujeitos envolvidos com a Associação LGBT ${ }^{9}$ do município do Rio Grande/RS. A escolha dos/as entrevistados/as, segundo Alberti (2005, p.31), "é, em primeiro lugar, guiada pelos objetivos da pesquisa". Assim, é interessante que tenhamos antes um conhecimento maior acerca da vida de tais sujeitos, a fim de compreender se eles teriam interesse ou náo pela participação na pesquisa. A escolha efetiva dos/as participantes deu-se através de um primeiro contato com o presidente da Associação e foi a partir do mesmo que chegamos aos/às demais entrevistados/as. O presidente, por sua vez, foi quem indicou e forneceu os contatos dos sujeitos que estavam interessados em participar e colaborar com a pesquisa e, então, entramos em contato com os/as mesmos/as, a fim de explanar sobre os objetivos da pesquisa, bem como sobre os procedimentos éticos ${ }^{10}$ adotados ao longo das entrevistas. As entrevistas foram filmadas para posterior transcrição das narrativas. Os/as entrevistados/as também receberam um Termo de Cessão, isto é, uma carta de autorização de uso das entrevistas na pesquisa, bem como de sua publicação. Quanto ao uso do nome dos/as participantes, entregamos também o Termo de Consentimento Livre e

vinculando apenas às minorias, mas a vários tipos de grupos sociais.

9 Abreviatura utilizada para lésbicas, gays, bissexuais, travestis e transexuais.

10 Os/as participantes da pesquisa receberam um Termo de Consentimento, o qual esclarece sobre: o uso do nome de cada entrevistado/a, a filmagem como facilitadora na transcrição e não para publicaçáo da imagem do/a entrevistado/a, informaçôes sobre a publicação. 
Esclarecido no qual cada sujeito declarou o nome a ser utilizado na pesquisa para sua identificação. Aqueles/as que optaram pelo anonimato, escolheram outros nomes para identificar-se. Apresentamos, a seguir, os sujeitos participantes desta pesquisa:

Véto: Optou pela utilização do nome pelo qual as pessoas o conhecem - Véto. Ele afirma que não tem que esconder nada de ninguém. Deixa a dica: Não sejam preconceituosos consigo. Mostrem a cara e exijam o respeito da sociedade. Véto nasceu no dia 6 de junho de 1977 e autoidentificou-se gay. Véto faz parte da Associação LGBT de Rio Grande, comenta que começou a participar da mesma a partir de um trabalho como fotógrafo em uma parada LGBT que ocorreu no município. [...] achei legal a luta, eu jamais iria me expor, talvez por um pouco de preconceito meu e achei legal aquela união, lutar por uma causa, pensei: Eu vou lutar junto, vou dar minha cara a tapas.

Naraya Luisa Brum: Aceitou utilizar seu nome social, Naraya Luisa Brum, na pesquisa, porque as pessoas a conhecem por esse nome. Ela comenta que dificilmente a chamam pelo seu nome civil; somente algumas pessoas da sua família. Naraya nasceu no dia 29 de julho de 1987 e autoidentificou-se como transexual. Ela é participante da Associação LGBT de Rio Grande e, sobre isso, comenta: Gosto de participar porque eu penso muito no mercado de trabalho para as bichas, porque vai ser um futuro pra mim.

Maria Regina: Optou por utilizar seu nome social, Maria Regina, na pesquisa, para que as pessoas conheçam a sua história que, segundo ela, é uma história original. Maria Regina acredita que as pessoas têm que saber a história dos/as outros/as. Ela considera que é conhecendo a história do próximo que a mente vai se abrir para outras coisas. Nasceu no dia 4 de agosto de 1979, autoidentificou-se como transexual e está no processo de mudança de sexo.

Ricardo: Não fez uso de seu próprio nome na pesquisa, por motivos de segurança; ele tem medo que alguém não goste do seu depoimento e que façam alguma coisa (agressão) com ele. Nasceu no dia 25 de fevereiro de 1988 e autoidentificou-se e reconhece-se como gay.

Léo: Optou por usar este nome na pesquisa porque, desde que começou a trabalhar como cabeleireiro, as pessoas o chamam de Léo. Ele afirma: Não vejo problema que as pessoas saibam da minha história, até porque eu sou assumido, sou bem aceito pela minha família. E eu me amo do jeito que sou, porque sou um ser como qualquer outro [...]. Léo nasceu no dia 16 de maio de 1993 e autoidentificouse como gay. 
Cindy: Embora em seu local de trabalho algumas pessoas a chamem pelo nome civil, na pesquisa optou por usar o nome social, Cindy. Ela afirma que não vê problemas quanto ao fato das pessoas conhecerem a sua história. Seu nome social é utilizado desde a primeira vez que se travestiu. Cindy nasceu no dia 3 de março de 1986 e autoidentificou-se como travesti.

Luciana Guerra: Não tem motivos específicos, mas optou por não utilizar o seu próprio nome, civil e social, na pesquisa. Nasceu no dia 28 de março de 1981, autoidentificou-se como transexual e afirma que nunca se sentiu um homem homossexual, porque nunca gostou de homens. Hoje entende-se como homossexual, porque tem uma identidade de gênero feminina e gosta de mulheres. Eu sempre gostei de mulher, comenta Luciana Guerra.

Robert: Optou pela utilização do seu próprio nome, civil e social, na pesquisa, porque afirma que esta é a sua história, esta é a sua verdade. Considera importante sua identificação, uma vez que está na luta por reconhecimento, na luta por igualdade, na luta por visibilidade. Robert é presidente da Associação LGBT de Rio Grande. Nasceu no dia 7 de setembro de 1967 e reconhece-se como gay.

As narrativas são analisadas a partir de algumas ferramentas propostas por Michel Foucault. Neste sentido, entendemos discurso como

[...] um conjunto de enunciados, na medida em que se apoiem na mesma formação discursiva; ele não forma uma unidade retórica ou formal, indefinidamente repetível e cujo aparecimento ou utilização poderíamos assinalar (e explicar se for o caso) na história; é constituído de um número limitado de enunciados para os quais podemos definir um conjunto de condições de existência. (FOUCAULT, 2005, p.132-133).

Por este viés, problematizamos, a partir de enunciaçóes, um dos enunciados que integra o discurso da homossexualidade dos sujeitos participantes deste estudo. Operamos com o conceito de enunciado, entendendo-o como “[...] uma função que cruza um domínio de estruturas e de unidades possíveis e que faz com que apareçam, com conteúdos concretos, no tempo e no espaço." (FOUCAULT, 2005, p 98). Elencamos algumas enunciaçóes produzidas pelos sujeitos participantes, buscando entender as condiçóes de existência das mesmas e suas implicações na constituição das subjetividades, bem como atentaremos para suas dispersóes e as rupturas (FOUCAULT, 2005). Compreendemos as enunciaçóes, a partir de Foucault (2005), como um conjunto de regras que suportam, tornam possível e definem um enunciado, neste caso, o enunciado identificado como a constituiçáo da homossexualidade. 
Apresentamos as enunciaçóes e as análises produzidas sobre as mesmas, entendendo que outras poderiam, também, terem sido apontadas e fazer parte deste corpus de análise e, portanto, outros direcionamentos poderiam emergir. Entretanto, buscamos olhar aquelas que produzem significados no processo de constituição dos sujeitos que participaram deste estudo.

A partir da perspectiva foucaultiana, ao analisar as narrativas produzidas, não pretendemos interpretar o que está por detrás do que foi dito e sim analisar o que está posto, problematizar as condiçóes de existência e as relaçóes existentes entre as enunciaçóes destacadas. Para tanto, apresentamos as narrativas e o processo de análise produzido acerca das mesmas.

\section{As enunciações que atravessam a constituição da homossexualidade}

Nesta seção, analisaremos algumas enunciaçôes ${ }^{11}$ que constituem o enunciado em questão, entendendo de que forma tais sujeitos produzem suas subjetividades. Destacamos três modalidades ou cenas enunciativas - busca de uma explicaçáo e/ou gênese para a homossexualidade; o desejo como constituinte da subjetividade homossexual e as questóes de gênero e suas relaçóes com a homossexualidade - as quais complementam-se e evidenciam as articulaçôes que se estabelecem no processo de produção do eu.

A primeira cena enunciativa elencada para este processo de análise refere-se à busca por uma explicaçáo e/ou gênese acerca da homossexualidade ${ }^{12}$. As narrativas que seguem explicitam esse entendimento e fornecem subsídios para pensarmos nas conexóes que se estabelecem entre a enunciação em estudo, neste primeiro momento, e as demais que emergiram.

Cindy: [...] às vezes tu nasce com um gene assim ou, às vezes, tu ti descobre assim com alguém.

Ricardo: A pessoa já nasce gay. Ela não vira gay, ela já nasce. Eu acho que ninguém faz a pessoa virar gay. A pessoa já nasce assim, não adianta. [...] normal parece que eu já nasci gostando de homem.

${ }^{11}$ Diante do limite do número de caracteres indicado pela revista, elencamos somente algumas narrativas para compor o corpus de análise deste estudo. Neste sentido, não foi possível apresentar a totalidade produzida a partir das entrevistas realizadas.

${ }^{12}$ Com exceção de Luciana Guerra, os/as entrevistados/as autoidentificaram-se como gays antes de assumir a travestilidade e a transexualidade. Entretanto, não estamos afirmando que antes de assumir ser travesti ou transexual, o sujeito precisa identificarse como gay, como se fosse uma condição pré-estabelecida. 
Léo: [...] eu nasci assim [...]. Não é uma opção de escolha [...].

Naraya Luisa Brum: Para mim geneticamente tudo é dentro da barriga. [...] porque opção não existe. Tu não vai escolher ser, tudo é uma orientação, orientação da cabeça. Tu vais achando aquilo meio estranho, mas as pessoas acham que tu escolhe, que tu pode mudar.

Maria Regina: Eu acho que isso já está no meu DNA; sinceramente, eu acho.

Robert: Tem várias teorias, mas eu tenho certeza que é intrinseco. Isso nasce com a pessoa. Eu não sei; não consigo fazer ideia de como isso nasce, o que é, onde está, se é no gene, em que lugar. Acho que ninguém sabe, mas acredito que isso realmente éteun.

Evidencia-se, a partir das narrativas apresentadas, que os sujeitos, ao afirmarem que nasce-se gay, buscam, através do discurso científico, explicar a "origem" ou a causa da homossexualidade. Por esse viés, o estatuto da natureza e, consequentemente, da normalidade é utilizado para justificar, conferir legitimidade e "verdade" à homossexualidade. Neste sentido,

[...] procurar uma tal origem é tentar reencontrar "o que era imediatamente", o "aquilo mesmo" de uma imagem exatamente adequada a si; é tomar por acidental todas as peripécias que puderam ter acontecido, todas as astúcias, todos os disfarces; é querer tirar todas as máscaras para desvelar enfim uma identidade primeira. (FOUCAULT, 2004a, p.13).

A partir das enunciações que buscam explicar e "tornar natural" a subjetividade homossexual, estabelece-se uma vontade de verdade que, conforme comenta Foucault (2009), é apoiada sempre em um sistema institucional. Ela sustenta-se a partir de estudos, testes, saberes científicos desenvolvidos em instâncias como, por exemplo, os laboratórios e, a partir de práticas e pesquisas específicas, que buscam encontrar e "comprovar" as causas e explicaçôes para a homossexualidade.

Os saberes produzidos pela ciência, e que de certa forma são usados para explicar a homossexualidade, atuam como regime de verdade que marcam a episteme ${ }^{13}$ moderna. Tais saberes são constituídos pela sociedade, que institui quais são os discursos verdadeiros. Entendemos a ciência como uma produção, um processo, uma construção, que "não reproduz uma verdade; cada ciência

13 Utilizamos o conceito de episteme a partir de Foucault (2005), entendendo-a como um dispositivo que permite elencar os enunciados que compreendem determinado campo de cientificidade de determinada época e momento histórico. 
produz a sua verdade" (MACHADO, 2006, p.19). Partindo do pressuposto de que a ciência é um processo, não há como definir que ela expressa uma verdade (MACHADO, 2006), já que os conhecimentos científicos são provisórios. Entretanto, os discursos produzidos por esse campo de saber - a ciência circulam na contemporaneidade assumindo um caráter de legitimidade.

Nesse contexto, os discursos produzidos no âmbito médico, psicológico, biológico, que circulam na sociedade, também interpelam os sujeitos gays, travestis e transexuais que se utilizam desses argumentos, em alguns momentos, para elaborar explicaçóes "naturais" para a sua homossexualidade. Entretanto, tais discursos, de certa forma, contribuem para caracterizar tal subjetividade como um "desvio" da normalidade heterossexual, como se a homossexualidade fosse um problema a ser resolvido ou algo passível de tratamentos, intervençóes médicas e psicológicas. Os sujeitos que participaram desta pesquisa buscam explicar e evidenciar que a homossexualidade é algo "natural", uma vez que nasceram gays, contribuindo, dessa forma, para aceitação de si e se deslocando, portanto, da ideia de desvio.

No interior das relaçóes de poder, o conceito de desvio sugere que existem comportamentos idealizados, que respondem a determinados valores que produzem "harmonia" com as expectativas socialmente construídas e pactuadas. O desvio não se configura em si, ele é resultado de relaçóes entre sujeitos que apontam outros de estarem com seus comportamentos destituindo as normas, os limites e os valores socioculturais (VELHO, 1989; CAETANO, 2005; GOFFMAN, 1988). Assim, aqueles sujeitos que não correspondem ao "padrão" hegemônico sexual (a heterossexualidade) e às expectativas de gênero em relação ao sexo biológico, são pré-definidos como "anormais" ou "desviantes", portanto, passíveis de serem analisados.

Para Louro (2004, p.29-30),

[...] ousando se expor a todas as formas de violência e rejeição social, alguns homens e mulheres contestam a sexualidade legitimada e se arriscam a viver fora dos seus limites. A Ciência, a justiça, as igrejas, os grupos conservadores e os grupos emergentes iráo atribuir a esses sujeitos e as suas práticas distintos sentidos. [...] Enquanto alguns assinalam o caráter desviante, a anormalidade ou a inferioridade do homossexual, outros proclamam sua normalidade e naturalidade - mas todos parecem estar de acordo de que se trata de um 'tipo' humano distintivo.

As enunciações no âmbito do discurso científico (nasce-se gay, nascese com um gene que determina a homossexualidade) são utilizadas como um determinante da homossexualidade, ou seja, os sujeitos buscam encontrar a verdade sobre a homossexualidade, a fim de fundamentá-la a partir desse saber 
que não é produzido por qualquer sujeito ou instância, mas sim é aquele que emerge das vozes ditas autorizadas. Ou seja, "[...] a verdade das ciências continua sendo guiada por uma vontade (histórica) de verdade que exclui outros saberes incabíveis na sua ordenação e distribuição." (CANDIOTTO, 2010, p.56). Se a homossexualidade foi ou ainda é entendida como um desvio, como uma aberração da natureza, ou ainda como uma anormalidade, a partir dessas narrativas, intenta-se que a ciência explique o motivo pelo qual se foge da norma. Neste sentido, se os sujeitos gays são caracterizados como desviantes da norma, ao colocar em evidência uma verdade e uma explicação para tal "inconformidade", de certa forma justifica-se a mesma.

Além disto, há uma busca pela naturalização da homossexualidade, a qual entendemos, neste estudo, como uma forma de aproximação à heterossexualidade. Fundamentar a homossexualidade como algo inato é uma maneira de torná-la "igual" à heterossexualidade, que sempre foi vista como "constituída na natureza das espécies" (SOUZA FILHO, 2009, p.99). Não consideramos que exista uma explicação natural ou uma natureza previamente estabelecida em relação à homossexualidade, mas partimos do pressuposto de que a homossexualidade, assim como a heterossexualidade, é uma construção social. A homossexualidade constrói-se historicamente e, portanto, pode ser modificada na e pela história, pelo sujeito em si ou de maneira coletiva.

Foucault (2011) propóe entendermos a homossexualidade como um modo de vida, buscando inventar uma maneira de ser a partir de um trabalho - o qual ele chama de ascese homossexual - de invenção sobre si. Ela institui novas maneiras de ser, novas formas de vida, novas amizades, novas culturas, novas relaçóes. $\mathrm{O}$ autor destaca que mais importante do que descobrir a verdade sobre o seu sexo, é usar "de sua sexualidade para chegar a uma multiplicidade de relações” (FOUCAULT, 2004b). É possível evidenciarmos, também, nas narrativas, que a homossexualidade pode ser construída a partir de relaçóes com o/a outro/a. Neste sentido, "[...] as experiências e as significaçóes da vida nunca atuam na relação única consigo mesmo; elas devem seu conteúdo e extraem sua validade das relaçóes interindividuais que o sujeito encontra em suas primeiras redes de pertencimento." (DELORY-MOMBERGER, 2008, p.59). As redes de sociabilidades também orientam a constituição dos sujeitos, possibilitando que a homossexualidade seja produzida através de relaçóes com outros sujeitos sociais. Esse entendimento é expresso e discutido nas próximas narrativas e análises, em que os/as entrevistados/as deixam evidente que sua homossexualidade assume certa visibilidade e reconhecimento a partir do sentimento de desejo pelo/a outro/a.

Por este viés, o desejo pelo/a outro/a configura a outra cena enunciativa que está atrelada ao enunciado discutido e que se articula com o que foi dito até o momento. 
Léo: Em primeiro lugar, eu me entendi como homossexual aos doze anos [...] Eu não entendia muito o que era ser homossexual [...] Com doze anos, eu comecei a entender, mas eu não me aceitava [...] Foi quando eu vi um tio meu, que ele é lindo e começou a me despertar alguma coisa, sendo que depois dali, eu sabia que eu era homossexual.

Véto: Desde que me conheço por gente, mais ou menos com uns sete anos, eu já sentia isso. É porque eu lembro que, naquela época, eu tinha olhar pra outros homens mesmo, mesmo com sete anos, mesmo inocente [...] Eu olhava com atração pra outros homens. Não crianças na minha idade; eu olhava pra pessoas mais velhas, 14/15/16 anos.

Ricardo: [...] desde então, eu comecei a gostar de homem. Eu nunca mais me interessei por mulher. Eu ia pra rua e olhava algum homem, eu queria agarrar o homem (risos). E da mulher eu tinha nojo. Eu tinha nojo de pensar que um dia eu ia ter que beijar uma mulher na boca. Era nojo disso, de beijar, de me relacionar, porque eu não gosto de mulheres.

Maria Regina: [...] mas está dentro de mim, porque eu me entendo por homossexual desde os sete anos. Eu me lembro que, quando eu fui pro jardim, eu não gostava da minha coleguinha; eu gostava do meu coleguinha.

Robert: [...] já quase na fase adulta, por volta dos 18 anos. [...] meu desejo deixou de ser interno e passou a ser explorado [...] eu já tava no exército, já tinha bastante tempo de exército [...]quando aconteceu com uma pessoa do mesmo sexo. Apesar do exército, de todas as forças armadas serem mundos especificamente masculinos, é exatamente no mundo masculino que há a homossexualidade masculina. Então, não tem lugar melhor (risos), vamos dizer assim, pra se exercitar o sexo. Foi no exército que isso aconteceu de forma real, verdadeira, de forma concreta.

Luciana Guerra: Na primeira série, eu acabei gostando de uma menina; e eu gostava dela de uma maneira diferente assim, eu gostava dela com o intuito de beijar ela, de namorar, aquela coisa bem inocente de criança mesmo, mas eu também tinha uma admiração por ela, como ela era, a aparência dela.

O desejo é destacado, nas enunciações, como um aspecto que define e justifica a homossexualidade. Ele é um sentimento que caracteriza e possibilita o reconhecimento de si como homossexual, travesti e transexual, uma vez que é a partir do desejo pelo/a outro/a que é possível compreender a própria subjetividade. Nesse contexto, o desejo assume uma posição central nesse processo de identificação e reconhecimento de si. Segundo Foucault (2004b), é com e através de nossos desejos que novas formas de se relacionar, de amar e novas formas de criação estabelecem-se. 
Por este viés, a homossexualidade é uma entre as múltiplas formas de relaçóes que se instauram na sociedade. Compartilhamos com o entendimento de Preciado (2010) que, ao discorrer sobre o desejo, não está referindo-se "[...] à noção psicanalítica ou inconsciente de desejo, mas como o prazer e o corpo que se estrutura em uma rede de relaçóes." (tradução nossa). O desejo não é natural, mas constituído/elaborado nas relaçóes em que se formam os sujeitos. Nesta perspectiva, o sentimento de desejo pelo/a outro/a é uma das enunciaçóes que sustenta o enunciado que nomeamos como a constituição da homossexualidade dos sujeitos entrevistados, a qual constrói-se na relação com o/a outro/a e, também, na negação do/a outro/a.

Foucault (2007) investigou a questão do sujeito de desejo a partir da experiência grega. No entanto, ao trabalharmos com este entendimento, não pretendemos, como também não fez Foucault, transpor o que ocorrera da era grega para o presente, buscando explicar as experiências atuais, mas entender como os sujeitos constituíram-se como sujeitos desejantes e também sujeitos de uma sexualidade. Por esse viés, Foucault (2007, p.11) buscou

[...] analisar as práticas pelas quais os indivíduos foram levados a prestar atenção a eles próprios, a se decifrar, a se reconhecer e se confessar como sujeitos de desejo, estabelecendo de si para consigo uma certa relação que lhes permite descobrir, no desejo, a verdade de seu ser [...]. Em suma, a ideia era a de pesquisar [...] de que maneira os indivíduos foram levados a exercer sobre eles mesmos e sobre os outros, uma hermenêutica do desejo [...].

Nesta perspectiva, é possível evidenciar, a partir das narrativas, que os sujeitos "descobrem" e entendem quem são a partir do desejo que sentem pelo/a outro/a, entendendo dessa forma a própria sexualidade. Neste sentido, “[...] o desejo é sempre o modo de produção de algo, o desejo é sempre o modo de construçâo de algo." (GUATTARI; ROLNIK, 2011, p.261). Parece que o desejo é produtor de algo que está dado, ou seja, se o sujeito sente determinado tipo de desejo, aloca-se ou é alocado em determinado local/identidade. Segundo Foucault (2008, p.95), o desejo aparece no século XVIII, como um motivador de açóes,

[...] o desejo é aquilo por que todos os indivíduos vão agir. Desejo contra o qual não se pode fazer nada. [...] O desejo é a busca do interesse para o indivíduo. $\mathrm{O}$ indivíduo, de resto, pode perfeitamente se enganar, em seu desejo, quanto ao seu interesse pessoal, mas há uma coisa que não engana: que o jogo espontâneo ou, em todo caso, espontâneo e, ao mesmo tempo regrado do desejo permitirá de fato a produção de um interesse, de algo que é interessante para a própria população. Produção do interesse coletivo pelo 
jogo do desejo: é o que marca ao mesmo tempo a naturalidade da população e a artificialidade dos meios criados para geri-la.

Partindo desse pressuposto, os sujeitos constroem sua história a partir de relaçóes de prazer e desejo com o/a outro/a. O desejo manifesta-se e se produz na relação com o próprio corpo e na relação com o/a outro/a a partir de gestos, atos, práticas de si, que constituem estratégias de uso dos prazeres.

Nas narrativas apresentadas também evidencia-se o quanto a homossexualidade, por exemplo, constrói-se a partir da negação dos atributos tidos como as expectativas de seu sexo biológico. É interessante destacar que a constituição da subjetividade projeta-se na mesma lógica heteronormativa dicotômica. Rejeitar a heterossexualidade e, portanto, tornar a homossexualidade como algo dizível (ERIBON, 2008) é uma maneira de atribuir autenticidade à homossexualidade. Neste sentido, "[...] toda fala que consiste em dizer a homossexualidade só pode, por conseguinte, ser ouvida com uma vontade de afirmá-la, exibi-la, como um gesto de provocação ou um ato militante." (ERIBON, 2008, p.131, grifo do autor). A partir das narrativas, evidenciamos que há uma afirmação da própria homossexualidade com o propósito de adesão/ aceitação de si mesmo.

Além desse aspecto, enfatiza-se que o "estar fora" das redes pessoais mais próximas é uma estratégia que facilita o processo de assumir uma prática homossexual. O exército, por exemplo, foi citado como uma instância propícia para externar o desejo pelo outro que, por muito tempo, foi considerado interno. É, muitas vezes, longe dos olhares reguladores daqueles que estiveram próximos na maior parte da vida que se estabelecem as condiçóes de viver a sexualidade a partir da relação com o outro que está no mesmo espaço.

Em meio a essa rede enunciativa, é possível destacar que a escola é outra instância que também participa da constituição dos sujeitos, uma vez que ela, a partir de seus discursos institui as formas como devemos agir na sociedade. É nesse espaço, também, que as relaçóes com os sujeitos ao nosso redor estreitam-se e as interações contribuem para o reconhecimento dos mesmos enquanto tais. A escola, portanto, com sua arquitetura, seu funcionamento, a partir de regras e discursos normativos é um dos principais e, talvez, o mais significativo espaço de educação para os gêneros e para a sexualidade. É nesse ambiente - disciplinar, regulatório e normativo - que se estabelece e se aprende quais os limites dos nossos corpos, de nossas açôes, de nossos gestos, de nossas posturas, da nossa fala, de nossos desejos, entre outras questóes, a partir das quais ensina-se e que aprendemos que deve haver uma uniformidade entre os gêneros e uma hegemonia heterossexual, bem como uma normalidade corporal. 
Em relação a essa uniformidade entre os gêneros, a outra cena enunciativa destacada e que emergiu nas narrativas de quase todos/as os/as entrevistados/as ${ }^{14}$ vincula-se às questóes de gênero e suas relaçóes com a homossexualidade. Indagados/as sobre quando e como começaram a se identificar como gays, e consequentemente, justificar sua homossexualidade, eles/as utilizam-se dessas enunciaçôes, no âmbito das questôes de gênero, para indicar quais foram os primeiros atributos na infância, elencados como parte da sua constituição.

Cindy: Por náo gostar das coisas convencionais que meninos gostavam, de jogar futebol.

Véto: Eu acho que todos nós fugimos desses padróes, né? Na infância, é brinquedo com boneca, de casinha, mas pra minha familia não foi tão estranho, porque eu tenho quatro irmãs. Então, a convivência com elas fez com que o pessoal pensasse, é porque vive no meio de mulheres.

Léo: Eu sempre tive atitudes. Eu brincava de boneca, eu gostava sempre de ser a Barbie.

Naraya Luisa Brum: [...] eu brincava de Barbie com as minhas primas e, quando a gente brincava de escolinha eu sempre era a professora. Às vezes, nas brincadeiras, eu me vestia de mulher.

Maria Regina: Quando eu era criança, eu tinha horror de brinquedo de menino. Eu me lembro que brincava de casinha [...] sempre gostei de coisas femininas mesmo.

Ricardo: Quando eu era menor, era criança, eu brincava de Xuxa, colocava a saia da minha mäe, [...] um guardanapo na cabeça pra fazer de cabelo, brincava assim [...].

Robert: A gente, quando é criança, tu sabes que existe algo diferente em ti, o jeito que tu pensas sobre as coisas, como que tu brincas, o tipo de brincadeiras que tu queres, quais as coisas que tu gostas, por quem que tu te interessas. Eu lembro desde sempre de já brincar e já me interessar por coisas diferentes. Tanto que a minha irmá fazia bonecas para eu brincar.

Os marcadores sociais que distinguem os gêneros, masculino e feminino, definem aquilo que pode e não pode ser feito pelos sujeitos. Ultrapassar as

14 Enfatizamos que essa questão emerge nas narrativas de quase todos os sujeitos, com exceção nas de Luciana Guerra, que afirma que nunca se sentiu um homem homossexual, porque sempre teve atraçáo afetivo-sexual por mulheres. Luciana Guerra se identifica como transexual lésbica. 
fronteiras de cada gênero - atitudes, gestos, posturas, modos de ser e se portar na sociedade - é uma maneira de colocar sob suspeita a própria sexualidade. Escapar às normas estabelecidas socialmente aos gêneros pode ser considerado um indicador de desvio da sexualidade dita normal, uma vez que ser homem e mulher, na sociedade, possui suas representaçôes e significados que devem ser seguidos à risca. A sexualidade "desviante" acaba por fragilizar ou borrar as fronteiras.

As narrativas evidenciam que escapar de tais "marcas de gênero", estabelecidas socialmente, contribuem para que os sujeitos justifiquem o reconhecimento de si como sujeito homossexual, buscando estabelecer uma coerência na construção das suas subjetividades. Ao falar em coerência, não estamos referindo-nos à coerência no sentido da inteligibilidade cultural proposta por Butler (2010, p.38), quando refere-se às "[...] leis que buscam estabelecer linhas causais ou expressivas de ligação entre o sexo biológico, o gênero culturalmente constituído e a 'expressão' ou 'efeito' de ambos na manifestação do desejo sexual por meio da prática sexual.”, mas sim no sentido de que é como se nos corpos desses sujeitos já tivessem sido tatuadas as experiências de si desde o nascimento, experiências essas que fazem menção às vivências em relação aos gêneros na infância. Operamos com o conceito de experiência problematizado por Larrosa (1994, p.43), o qual afirma

[...] que a própria experiência de si não é senão o resultado de um complexo processo histórico de fabricação no qual se entrecruzam os discursos que definem a verdade do sujeito, as práticas que regulam seu comportamento e as formas de subjetividade nas quais se constitui sua própria interioridade. [...] A experiência de si, historicamente constituída, é aquilo a respeito do qual o sujeito se oferece seu próprio ser quando se observa, se decifra, se interpreta, se descreve, se julga, se narra, se domina, quando faz determinadas coisas consigo mesmo, etc. E esse ser próprio sempre se produz com relação a certas problematizaçôes e no interior de certas práticas.

Esse processo de inventar e reinventar, de fabricar-se, de narrar-se dos sujeitos gays, travestis e transexuais, é construído em meio às relaçóes que se estabelecem na sociedade. Neste sentido, tais sujeitos buscam dar sentido a quem são, a partir de discursos produzidos na e pela sociedade. Nas narrativas apresentadas, podemos evidenciar que os sujeitos buscam um caráter de normalidade e justificativa para a homossexualidade, já que afirmam que é na infância que percebem o interesse pelas "coisas" ditas do gênero masculino e do gênero feminino, que se opóem ao seu sexo biológico. Tais sujeitos buscam, a partir dessas questóes, uma maneira de fundamentar, legitimar sua subjetividade 
na busca de uma explicação no âmbito da normalidade. Esses sujeitos buscam atribuir às subjetividades consideradas desviantes - gays, travestis e transexuais um caráter de normalidade, a partir da consideração de que a homossexualidade, por exemplo, é, desde a infância, parte de sua constituição, o que evidencia que, para eles/as, a homossexualidade não é um desvio ou uma anormalidade, mas sim algo "natural", já que destacam fatos vivenciados no início de suas vidas que justificam esse entendimento.

\section{Tecendo (in)conclusões}

"Existem momentos na vida onde a questáo de saber se se pode pensar diferentemente do que se pensa, e perceber diferentemente do que se vê, é indispensável para continuar a olhar ou a refletir." Foucault (2007, p.13).

Ao finalizar este texto, não consideramos esgotadas as possibilidades de reflexóes e de olhares sobre o material produzido e apresentado neste artigo. As análises produzidas evidenciam um olhar entre os múltiplos que poderiam ter sido abordados, ou seja, outros vieses poderiam ter sido atribuídos às enunciaçóes destacadas, bem como outras poderiam ter sido apontadas. Nosso objetivo em analisar as enunciaçóes que emergiram neste estudo, conforme já mencionamos, não consistiu em buscar desvelar algo detrás das narrativas apresentadas, mas sim olhar tais enunciaçóes, reconhecê-las e entender as conexôes estabelecidas entre as mesmas, buscando compreendê-las em sua relação com a constituição da homossexualidade, que é um dos enunciados que constituem o discurso da homossexualidade.

O processo de análise empreendido neste trabalho, portanto, possibilitounos destacar três cenas enunciativas que atravessam a constituição dos sujeitos participantes deste estudo. A primeira cena enunciativa elencada para análise refere-se à busca de uma explicação ou origem para a homossexualidade, em que as narrativas apontam que os sujeitos intentam, a partir do discurso científico, justificar o por quê "desviam da norma", ou seja, porque são gays, travestis e transexuais, bem como legitimar sua subjetividade a partir de uma vontade de verdade. A segunda diz respeito ao desejo pelo/a outro/a como marcador das subjetividades gays e, posteriormente, travestis e transexuais. Neste sentido, os sujeitos apontam o quanto o desejo pelo/a outro/a contribui para entender-se e identificarem-se como tais. A última cena enunciativa destacada aponta para as questôes de gênero atreladas a esse processo de identificação e reconhecimento como gay, travesti e transexual. Os/As entrevistados/as narram fatos ocorridos no decorrer de suas vidas, principalmente durante a infância, buscando, de certa forma, estabelecer uma coerência na construção das suas subjetividades, 
explicando, a partir de suas experiências, as relaçóes estabelecidas entre a homossexualidade e as questóes de gênero.

Essas três cenas enunciativas que formam o enunciado da constituição da homossexualidade, potencializam, ao nosso ver, a produção do discurso da homossexualidade, evidenciando que as questóes discutidas nessas enunciaçóes perpassam a homossexualidade dos sujeitos entrevistados. O discurso da homossexualidade, portanto, adquire visibilidade a partir dessas enunciações.

Salientamos que o entrecruzamento das enunciaçóes elencadas para discussão neste artigo, possibilita entendermos como constituem-se os sujeitos que participaram deste estudo e quais são as práticas de si e as estratégias de fabricação de si envolvidas nesse processo de produção de suas subjetividades.

As narrativas analisadas são produzidas por "vozes" de diferentes sujeitos; no entanto, elas encontram-se constituindo um mesmo e determinado enunciado que ao se entrelaçar com os demais, forma essa rede enunciativa que compóe o discurso da homossexualidade dos sujeitos. Esse processo de construção do eu, de (re)invenção de si compreende novas maneiras de ser e estar no mundo, novas formas de relaçóes, novos modos de vida, outras possibilidades de viver os desejos e os prazeres.

As enunciações elencadas referem-se à constituição dos sujeitos de uma determinada época e contexto social, e inscrevem-se no dispositivo da sexualidade da contemporaneidade. Esse dispositivo trata da produçáo da sexualidade a partir de múltiplos discursos, práticas, saberes, poderes, prazeres, que compreendem determinado momento histórico, político, cultural e também social. Os sujeitos constituem-se a partir desses discursos, circundantes na sociedade, que produzem efeitos na sua construção biográfica.

O $E u$ atualizado do discurso é a forma primeira na qual se institui o sujeito: é o Eu que me inscreve, ao mesmo tempo, como sujeito-narrador e como sujeitoator da história que conto sobre mim mesmo. [...] o sujeito é essa figura flexível e movente a quem é dado compreender-se como autor de sua história e dele mesmo. (DELORY-MOMBERGER, 2008, p.99, grifo do autor).

A partir das narrativas, evidenciamos que os sujeitos constroem as suas subjetividades nas relaçóes que se estabelecem com o/a outro/a na sociedade. A relação com o/a outro/a e com a história do/a outro/a possibilita que a própria história seja construída. Entretanto, cada sujeito compóe a sua história com todas as suas singularidades, as suas particularidades a qual é narrada pelo próprio sujeito, que é o/a autor/a dessa história. As narrativas analisadas não totalizam a história de cada um/a, mas evidenciam os caminhos trilhados por eles/as, os quais possibilitam-nos compreender como se constituíram, como se entendem enquanto sujeitos de uma sexualidade e como se produzem a partir de suas experiências de vida, ou seja, a partir de suas artes de existência. 


\section{REFERÊNCIAS}

ALBERTI, V. Manual da história oral. 3.ed. Rio de Janeiro: Fundação Getúlio Vargas, 2005.

BUTLER, J. Problemas de gênero: feminismo e subversão da identidade. 3.ed. Rio de Janeiro: Civilização Brasileira, 2010.

CANDIOTTO, C. Foucault e a crítica da verdade. Belo Horizonte: Autêntica; Curitiba: Champagnat, 2010.

CAETANO, M. R. V. Gênero e sexualidade: um encontro político com as epistemologias de vida e os movimentos curriculares. 2011. 228p. Tese (Doutorado em Educaçáo) - Faculdade de Educação, Universidade Federal Fluminense, Rio de Janeiro, 2011.

Os gestos do silêncio para esconder as diferenças. 2005. [157]p. Dissertação (Mestrado em Educação) - Universidade Federal Fluminense, Rio de Janeiro, 2005.

DELORY-MOMBERGER, C. Biografia e educação: figuras do indivíduo projeto. Natal: EDUFRN; São Paulo: Paulus, 2008.

ERIBON, D. Reflexóes sobre a questáo gay. Rio de Janeiro: Companhia de Freud, 2008.

EWALD, F. Foucault e a norma. In: EWALD, F. (Org.). Foucault, a norma e o direito. Lisboa: Veja, 1993. p. 77-125.

FOUCAULT, M. Da amizade como modo de vida gay. Disponível em: <http://portalgens. com.br/portal/images/stories/pdf/amizade.pdf>. Acesso em: 19 ago. 2011.

Ética, sexualidade, política: ditos e escritos V. 2.ed. Rio de Janeiro: Forense Universitária, 2010a.

O sujeito e o poder. In: DREYFUS, H.; RABINOW, P. (Org.). Michel Foucault: uma trajetória filosófica: para além do estruturalismo e da hermenêutica. Rio de Janeiro: Forense Universitária, 2010b. p. 273-295.

A ordem do discurso. São Paulo: Ediçôes Loyola, 2009.

Segurança, território e populaçáo: curso dado no Collège de France (1977-1978). São Paulo: Martins Fontes, 2008.

História da sexualidade 2: o uso dos prazeres. Rio de Janeiro: Graal, 2007.

Arqueologia do saber. 7.ed. Rio de Janeiro: Forense Universitária, 2005.

Microfísica do poder. 20.ed. Rio de Janeiro: Graal, 2004a.

Michel Foucault, uma entrevista: sexo, poder e a política da identidade. Verve, São Paulo, n.5, p.260-277, 2004b. Disponível em: <http://revistas.pucsp.br/index.php/verve/ article/viewFile/4995/3537>. Acesso em: 11 ago. 2011.

Um diálogo sobre os prazeres do sexo. In: FOUCAULT, M. (Org.). Um diálogo sobre os prazeres do sexo: Nietzsche, Freud e Marx. Theatrum Philosoficum. São Paulo: Landy, 2000. p. 11-45. 
GOFFMAN, E. Estigma: notas sobre a manipulação da identidade deteriorada. Rio de Janeiro: Livros Técnicos e Científicos, 1988.

GREEN, J. Além do carnaval: a homossexualidade masculina no Brasil do século XX. São Paulo: Ed. da UNESP, 2000.

GUATTARI, F; ROLNIK, S. Micropolítica: cartografias do desejo. 11.ed. Petrópolis: Vozes, 2011.

LARROSA, J. Tecnologias do eu e da educação. In: SILVA, T. T. da (Org.). O sujeito da educaçáo: estudos foucaultianos. Petrópolis: Vozes, 1994. p. 35-86.

LOURO, G. L. Um corpo estranho: ensaios sobre sexualidade e teoria queer. Belo Horizonte: Autêntica, 2004.

MACHADO, R. Foucault: a ciência e o saber. Rio de Janeiro: Zahar, 2006.

MEIHY, J. C. S. B.; HOLANDA, F. História oral: como fazer, como pensar. 2.ed. São Paulo: Contexto, 2010.

PERES, W. S. Travestis, escolas e processos de subjetivação. Instrumento: Revista de Estudo e Pesquisa em Educaçáo, Juiz de Fora, v.12, n.2, p.57-65, jul./dez. 2010. Disponível em: <http://instrumento.ufjf.emnuvens.com.br/revistainstrumento/article/view/935/798>. Acesso em: 5 set. 2011.

Cenas de exclusóes anunciadas: travestis, transexuais, transgêneros e a escola brasileira. In: JUNQUEIRA, R. D. (Org.). Diversidade sexual na educaçáo: problematizações sobre a homofobia nas escolas. Brasília: Ministério da Educação, Secretaria de Educação Continuada, Alfabetização e Diversidade, 2009. p. 235-264.

PRECIADO, B. Las políticas del sexo y del deseo. Revista ñ, Buenos Aires, v.19, jun. 2010. Disponível em: <http://edant.revistaenie.clarin.com/notas/2010/06/19/_-02203127.htm>. Acesso em: 8 set. 2011.

SOUZA FILHO, A. de. Teorias sobre a gênese da homossexualidade: ideologia, preconceito e fraude. In: JUNQUEIRA, R. D. (Org.). Diversidade sexual na educaçáo: problematizaçóes sobre a homofobia nas escolas. Brasília: Ministério da Educaçáo, Secretaria de Educaçáo Continuada, Alfabetização e Diversidade, 2009. p. 95-124.

- Foucault: o cuidado de si e a liberdade ou a liberdade é uma agonística. In: ALBUQUERQUE JÚNIOR, D. M. de; VEIGA-NETO A.; SOUZA FILHO, A. de (Org.). Cartografias de Foucault. Belo Horizonte: Autêntica Editora, 2008. p.13-26.

VELHO, G. Desvio e divergência: uma crítica da patologia social. Rio de Janeiro: Zahar, 1989. 


\section{Resumo}

A (re)invenção de si no entrelaçar das enunciaçōes de gays, travestis e transexuais

O presente artigo tem, como objetivo, investigar a constituiçáo de sujeitos, os quais autoidentificam-se como gays, travestis e transexuais, problematizando algumas enunciaçóes envolvidas nos seus processos de subjetivação. Para tanto, analisamos narrativas desses sujeitos, a partir de algumas ferramentas propostas por Michel Foucault. Tais narrativas foram produzidas através da metodologia da História Oral. No processo de análise empreendido neste trabalho, destacamos três cenas enunciativas - a busca de uma explicação natural para a homossexualidade; o desejo pelo/a outro/a como marcador dessa subjetividade e as questóes de gêneros atreladas a esse processo de reconhecimento como gays, travestis e transexuais. Tais cenas enunciativas se entrelaçam e constituem o enunciado que nomeamos a constituiçáo da homossexualidade dos sujeitos que participaram desse estudo.

Palavras-chave: Constituição. Sujeitos. Homossexualidade.

\section{Abstract}

The (re)invention of oneself in the intertwining of statements: stories of gays, transvestites and transsexuals

Abstract: This article aims to investigate the constitution of subjects, who recognize themselves as gays, transvestites and transsexuals, questioning some statements and some of the practices involved in the processes of subjectification. For that, we analyzed the narratives of these subjects, using tools proposed by Michel Foucault. Such narratives were produced using the Oral History methodology. In the process of analysis used in this paper, we highlight three statements - the search for a natural explanation for homosexuality; the desire for the other as a marker of subjectivity; and gender issues linked to this process of recognition as gays, transvestites and transsexuals. They are all intertwined and form the enunciate that we name as constitution of homosexuality of the subjects who took part in this study.

Keywords: Constitution. Subjects. Homosexuality. 